\title{
Oficiais, cavalheiros e concorrentes: o «Brasil» nas viagens de circum-navegação do século das Luzes
}

\author{
por
}

\section{Ângela Domingues*}

Centro de História-Instituto de Investigação Científica Tropical

Centro de História de Além-Mar da FCSH da Universidade Nova de Lisboa

\begin{abstract}
Pretende-se analisar as imagens do Brasil através da literatura de viagens produzida com as expedições de circum-navegação da segunda metade do século XVIII. O modo como o Brasil foi representado nos relatos de Cook, Byron ou Bougainville e nas colectâneas que difundiram estas viagens não foi ainda devidamente considerado e apreciado. Esta avaliação é imprescindivel para perceber a importância da colónia a uma escala global, e sobretudo no Atlântico Sul e nos jogos de poder que então se desenrolavam. De igual modo, na tentativa de «dominar o mundo» ocorrida na Europa setecentista, a competição é fundamentalmente entre França e Inglaterra. Neste processo, a atenção que ambos países dão ao Brasil expressa-se em projectos de anexação, bem como na dominação informal, patente no peso que tinham o comércio ilegal e o contrabando britânicos ou o interesse e curiosidade científicos. Assim sendo, perceber a concorrência entre estes países também ao nível da literatura de viagens, da produção e disseminação da informação - e consequentemente da propaganda - pode contribuir para uma melhor compreensão do que o Brasil e Portugal significavam para a Europa setecentista.
\end{abstract}

PalaVRas-Chave: Brasil colonial; viagens de circum-navegação; literatura de viagens; impérios europeus; identidades.

O debate historiográfico que recentemente se tem gerado em torno de império e dos diferentes significados, características, caracterizações e explicações para a sua ascensão e declínio enfatiza o facto de que os impérios marítimos

* Agradeço a Manuela Portugal e Tiago Miranda a revisão do texto e as sugestões bibliográficas. 
da época moderna, por se estenderem por longitudes mais amplas e abrangerem vários tipos de biomas, i.e., por se caracterizarem por uma diversidade significativa de zonas ecológicas, biológicas e climáticas, imporem desafios, dificuldades e soluções complexas que os impérios terrestres e continentais, com características ecológicas, climatéricas e biológicas uniformes ou aproximadas, não suscitam.

Historiadores como Turchin, Adams e Hall, protagonistas deste debate, associam ainda a formação destes impérios marítimos de «efeito longitudinal» ao advento da tecnologia industrial e à ascensão do capitalismo moderno, e ao alargamento da consequente procura de novos produtos e recursos e de novos mercados, bem como a um maior envolvimento e um maior investimento por parte dos Estados ${ }^{1}$. Afirmam igualmente que este tipo de impérios levanta problemas de distância e comunicação, que se procuraram atenuar no século XVIII, quando, mercê da actividade exploratória de navegadores e cientistas, os mares se tornaram melhor conhecidos e mais seguros, e o mundo se tornou mais próximo.

Creio ser interessante perceber que estas relações entre «physical and biological environments» e império, um problema que se afigura de uma actualidade e uma pertinência acutilantes nos debates historiográficos mais recentes sobre a world history, podem encontrar eco e resvalar para a evocação da produção intelectual e cientifica europeia do século das Luzes, e não apenas para a que foi produzida pela «fina-flor» da intelectualidade mais elitista, como George-Louis Leclerc, conde de Buffon, ou Cornelius De Pauw, que, sem grandes rebuços, defendiam a teoria da debilidade ou inferioridade de um jovem continente americano e a degenerescência da natureza e humanidade nos trópicos, contribuindo para a legitimação da superioridade europeia e de direito a um imperialismo se não político pelo menos científico dos europeus ${ }^{2}$. Mas também por indivíduos menos intelectuais ou mais mentirosos e imbecis, como escreveu Bougainville evocando a sua situação de marinheiro e viajante.

O meu objectivo neste texto é analisar a imagem do Brasil através da literatura de viagens produzida com as expedições de circum-navegação da segunda metade do século XVIII. Uma pergunta que pode pertinentemente ser feita é a seguinte: o que de novo se poderá trazer a um tema já tão competentemente estudado como o das viagens de Cook, Byron ou Bougainville? Tanto quanto consegui perceber, e apesar de indubitavelmente reconhecer a novidade e o interesse de muitos estudos em torno destas viagens, parece-me

1 Turchin, Adams y Hall, XII / II (North Carolina e Utah, December 2006): 219-229. Turchin, 4 (Londres, 2009): 191-217.

${ }^{2}$ Gerbi, 1996. 
que a colónia brasileira tal como foi descrita neste relatos não foi ainda devidamente considerada e apreciada. Ora esta avaliação é imprescindível para perceber a importância da colónia a uma escala global, e sobretudo no Atlântico Sul e nos jogos de poder que então se desenrolavam na Europa. Importa-me, pois, perceber como o Brasil é descrito e o que nestas descrições se valoriza e é objecto de atenção dos viajantes, e que reflecte, de modo inegável, o que interessava à Europa e aos europeus da altura.

Mas há ainda uma outra questão que, no meu entendimento, concorre para a justa equação do objecto de estudo enunciado. Na tentativa de «dominar $o$ mundo» ocorrida na Europa setecentista, a competição é fundamentalmente entre França e Inglaterra. Neste processo, a atenção que ambos países dão ao Brasil expressa-se em projectos de anexação manifestados em vários momentos, bem como na dominação informal, expressa, por exemplo, no peso que tinham o comércio ilegal e o contrabando britânicos ou o interesse e curiosidade científicos. Assim sendo, perceber a concorrência entre estes países também ao nível da literatura de viagens, da produção e disseminação da informação - e consequentemente da propaganda - pode contribuir para uma melhor compreensão do que o Brasil significava.

Importa ainda clarificar um outro ponto, directamente relacionado com a forma como iniciei este texto. Numa tentativa de ultrapassar lugares-comuns que afirmam, sem procurar fundamentação para o fenómeno, que, por exemplo, o modo de representar a sociedade colonial luso-brasileira na literatura de viagens setecentista corresponde a clichés utilizados para os portugueses reinóis (sic), quero sublinhar que esta literatura de viagens produzida, compilada ou editada por estes europeus, homens (in)vulgares, tem implícitas, de forma límpida, noções tão pertinentes para os estudos de história como são as de império, dominação, identidade e superioridade, uma superioridade que é política mas é também cultural, religiosa e ética. Contribuem ainda para uma compreensão mais ampla de como a ciência, a par dos tão recorrentemente evocados motivos económicos que se recordam, por exemplo, para ilustrar as relações entre Portugal, a colónia brasileira e Inglaterra, pode ser também uma forma eficaz de imperialismo informal.

Depois da enunciação abstracta do tema que me ocupa, importa agora tentar desenvolvê-lo, começando por sumariar algumas questões que se afiguram pacíficas. 
1. As VIAGENS: UMA PRÁtica PROMOVIDA POR REIS, GOVERNOS E ACADEMIAS; UMA MODA QUE AFECTOU MARINHEIROS, AVENTUREIROS E CIENTISTAS

Nos inícios dos anos 1730, Portugal era considerado por alguns intelectuais, como Lafitau, como um país detentor de um passado glorioso mas em relação ao qual muito pouco se sabia porque quase nada havia sido publicado. De acordo com este historiador e naturalista jesuíta, especialista no estudo dos Iroquois e responsável pela descoberta do ginseng, a contribuição mais notável do país para a história da Europa consistiu nas descobertas e conquistas do «Novo Mundo», particularmente no que se relacionava com a difusão do cristianismo e a abertura de novas rotas que permitiam o acesso dos europeus aos tesouros e riquezas de países longínquos ${ }^{3}$. Lafitau expressava uma estupefacção entusiasta porque sendo Portugal um reino tão pequeno, «il n'etoit pas naturel de présumer qu'il put trouver en lui-même tant de ressources, former de si vastes entreprises, embrasser une aussi grande étendue de pays, fournir à tant des dépenses, subjuguer tant de peuples divers, \& mettre en œuvre un si grand nombre de sujets capables de faire réussir ses projets avec tant de gloire» ${ }^{4}$. Contudo, restringia esta admiração e circunscrevia este período de glória até ao início da dinastia filipina. Tornado parte da coroa de Espanha, Portugal viu as suas «conquistas» no «Novo Mundo» serem negligenciadas pelos monarcas castelhanos e as possessões tornarem-se objecto de cobiça por parte de Mogols, que cercam Ormuz, dos reis da Pérsia, que tomam Malaca e expulsam os portugueses das ilhas de Ceilão e Sonda, e de ingleses e holandeses, que ocupam parte do Brasil e afectam o comércio nas conquistas africanas $^{5}$.

No entanto, o cenário defendido em setecentos por este fervoroso admirador das glórias passadas lusitanas, fundamentado no enfraquecimento do Portugal desde a Monarquia Dual devido à perda da soberania nacional e a contestações múltiplas sentidas a nível global, é facilmente contestado. As rivalidades entre ibéricos e europeus do Norte, ocorridas à escala mundial, tiveram desfechos variados e se é incontestável que ingleses e holandeses obtiveram sucesso no Oriente, importa referir que na América e em África o quadro é bastante mais ambíguo.

A América do Sul continuava a ser partilhada pelas duas coroas ibéricas, que pretendiam ter um apertado controlo em relação à passagem e à permanência de súbditos de outras nações em território colonial. Citando Sanjay

\footnotetext{
${ }^{3}$ Lafitau, 1734: j.

${ }^{4}$ Ibidem: iij.

5 Ibidem: 690-3.
} 
Subrahmanyam, «Brazil notoriously remained intact as a Portuguese colony (...) continued through the later seventeenth and eighteenth centuries to be a powerful and vibrant motor in the Portuguese colonial system and linked nor simply to the metropolis but also to West Africa, in a South Atlantic trading system ${ }^{6}$. De igual modo, a Espanha procurou defender o seu império na América e os seus interesses nas Filipinas e Pacífico, nomeadamente através da modernização da marinha e da realização de viagens científicas continentais e marítimas. «Voyages to the Americas and the Pacific became a symbol of Spain's eighteenth-century recovery and were powered by a comparative duality: a political agenda involving military, strategic and commercial concerns. And a sincere desire to use and contribute to scientific progress and the expansion of knowledge»? .

É neste espaço marítimo que parte significativa das disputas de poder entre as potências europeias ocorre. As rotas atlânticas e os portos do Índico aumentam o peso que tinham no equilíbrio europeu e tenta-se adivinhar e atribuir uma importância estratégica crucial a pontos de apoio à navegação e à colonização no Pacífico. O fenómeno é simultaneamente político, estratégico e militar, ideológico e propagandístico, económico, científico e técnico. E espelha-se, por exemplo, na evolução da construção naval, no aperfeiçoamento do armamento dos navios, no peso económico dado ao transporte de mercadorias e na noção cada vez mais exacta do poder da marinha enquanto meio de poder e de bloqueio $^{8}$. Mas é igualmente claro nos espaços físicos em que os navios de várias nações se cruzam e na frequência com que o fazem, bem como nos motivos que estão subjacentes às viagens que realizam. E tem, ainda, uma dimensão específica e proeminente na literatura que marinheiros e viajantes produzem, que compiladores recolhem e transformam, que letrados e cientistas traduzem e que editores publicam; ou nas espécies animais, vegetais e minerais e nos objectos com interesse antropológico e etnológico que circulam a nível mundial.

Os homens que são protagonistas neste processo de navegação e apropriação de mares definem-no como sendo, por excelência, a época das viagens de circum-navegação. Mas, e conforme eles, com lógica incontestável, apontam, já desde o século XVI se realizavam viagens deste tipo. Fernão de Magalhães, Francis Drake, Cavendish, William Dampier, Edmund Cooke, Woodes Rodgers, Steven Courtney e Shelvocke tinham empreendido, durante a primeira metade desse século, viagens transoceânicas para apurar a existência de um

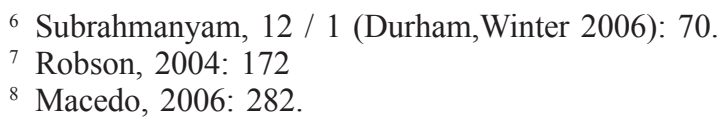

${ }^{8}$ Macedo, 2006: 282. 
hipotético continente no Pacífico que devia manter o equilíbrio do globo e, com esta descoberta de um grande continente, queriam obter glória, e também o ouro e as especiarias que Magalhães, Mendaña e Quirós não tinham descoberto, para benefício de Inglaterra ${ }^{9}$. Contudo, estas viagens, de que tinham resultado excelentes relatos, estavam longe de ter obtido os resultados que eram exigidos por filósofos e homens de ciência do período das Luzes: ao nível da geografia, da cartografia e do conhecimento dos povos ou das produções naturais. É nesta linha que se pode interpretar a avaliação que Bougainville faz dos resultados obtidos na viagem do almirante George Anson: «Le goût des grandes navigations paraissait entièrement éteint, lorsqu'en 1741 l'amiral Anson fit autour du globe le voyage dont l'excellente relation est entre les mains de tout le monde, et qui n'a rien ajouté à la géographie» ${ }^{10}$.

Quanto à cronologia das viagens subsequentes à do almirante britânico, é bem conhecida: após o período de interrupção imposto pela Guerra dos Sete Anos (1756-1763), o Almirantado britânico retoma o movimento de exploração, promovendo, organizando e financiando viagens como a de George Byron (1764-1766), Samuel Wallis (1766-1768), Philip Carteret (1766-1768), James Cook (1768-1771), seguidas de perto pelas dos franceses Louis-Antoine de Bougainville (1766-1769) e Jean-François de La Pérouse (1785-1788), e do toscano ao serviço da coroa espanhola Alejandro Malaspina (1786-1788) ${ }^{11}$. Estas viagens redireccionaram-se gradualmente do Atlântico Sul e da colonização das ilhas Falkland/Malvinas e Pepys (que, por razões diametralmente opostas, estão no centro das instruções de Byron e Bougainville), para os mares do Sul, em busca de uma grande massa territorial que se encontrasse livre da soberania ibérica $^{12}$. Ora nesse sentido, estas viagens de circum-navegação significavam também novas perspectivas de colonização e comércio. Como a natureza tinha favorecido uns locais da terra em detrimento de outros, dando-lhes novos e ricos produtos, era nesses locais que importava fundar colónias. A competição era entre Inglaterra e França, que procuravam com a exploração do Pacífico

\footnotetext{
9 Newell, 2003: 247.

${ }_{10}$ Bougainville, 2006: 10.

${ }^{11} \mathrm{O}$ intervalo entre as viagens de Bougainville e La Pérouse, de cerca de 14 anos, explicase pela queda dos ministros Choiseul e Praslin, que apoiavam o projecto de colonização defendido por Bougainville, e com a deslocação dos eixos de interesses franceses para o Indico e Europa. Neste interregno ocorreram as expedições privadas de Surville e Marion Dufresne (Robson, 2004: 158).

${ }_{12}$ Nos inícios do século XIX um outro império iria participar no processo exploratório do Pacífico. A Rússia preparou duas expedições científicas de circum-navegação: a de Adam Johann von Krusenstern (1803-1806) e a de Otho von Kotzebue (1815-1818). Junqueira, 25 (Niterói, Julho 2008): 130.
} 
obter o equilíbrio de poder na Europa, depois de os franceses terem cedido aos ingleses territórios no Canadá, Caraíbas e Índia ${ }^{13}$.

A questão que posso, então, colocar é a seguinte: o que, no entender destes indivíduos, diferenciava as viagens até aqui realizadas das que ocorriam na sua época. Ou seja, o que é que neste período se passou a valorizar e considerar neste tipo de empreendimentos?

Primeiro que tudo, estas viagens, embora tivessem contribuído para projectar e até mesmo mistificar alguns indivíduos, como foi o caso de James Cook ou Bougainville, não eram encaradas como sendo façanhas de indivíduos ou de grupos específicos, fossem estes aventureiros, piratas ou mercadores. Estas viagens eram feitas em nome de estados e nações, muitas vezes financiadas pelas coroas, favorecidas com o alto patrocínio e a atenção do monarca, e contribuiriam para glorificar a nação e o povo a que estavam filiadas ${ }^{14}$. Assim sendo, embora Guy Le Gentil de la Barbinais tenha sido dos primeiros franceses a dar a volta ao mundo, efectivamente a primeira viagem de circum-navegação francesa considerada é a de Bougainville: «Le voyage dont je vais rendre compte est le premier de cette éspece entrepris par les Français et executé par les vaisseaux de Votre Majesté»» ${ }^{15}$.

Em segundo lugar, estas viagens, realizadas em período de paz e quando os recursos navais, humanos, financeiros e intelectuais das nações se podiam maioritariamente concentrar nelas, tiveram eminentemente objectivos científicos com repercussões a nível politico, colonial e económico, e destinavam-se a contribuir para o bem-comum e a felicidade de indivíduos, nações e da humanidade, para além de concorrerem para a projecção dos europeus e da sua superioridade civilizacional e cultural à escala mundial: «Toutes les richesses du globe appartiennent à l'Europe que les sciences ont rendue souveraine des autres parties: allons donc recueillir cette moisson» ${ }^{16}$.

Das ciências se esperava a produção de um conhecimento útil, que decorria da exploração e do conhecimento do globo; um saber que tornava a navegação dos mares mais segura, uma vez que os novos instrumentos de

13 Idem. 130; Robson, 2004: 139.

${ }^{14} \mathrm{~V}$. por exemplo a relevância que se dá à forma como os descobrimentos de novas terras ou o aumento de conhecimentos em relação a terras já descobertas por Cook podem contribuir para a honra da nação como poder marítimo e para a dignidade da coroa britânica, a que se junta o desenvolvimento do comércio e da navegação (Secret instructions to captain Cook, 30 June 1768 in http://www.foundingdocs.gov.au/resources/transcripts/nsw1_doc_1768.pdf (acessado em 11.03.2011). François Moureau afirma que o prurido nacional é uma novidade do século XVIII (Moureau, 2005: 22).

15 Bougainville, 2006: 6.

${ }^{16}$ Carta de Bougainville a Choiseul in Bougainville, 2006: VII. 
medição e observação permitiam maior precisão no traçado de rotas e que estas eram cartografadas com maior precisão. Para além disso, estas viagens beneficiariam a formação de jovens oficiais e marinheiros porque constituíam uma «escola prática»: passavam por todos os climas, por todas as estações e submetiam-nos e preparavam-nos para as mais variadas situações.

As viagens tornariam, de igual modo, os povos mais felizes e prósperos, graças à exploração de riquezas naturais e à introdução das técnicas, junto dos não-europeus e em benefício dos europeus. «Dans un champ si vaste, il restera pendant bien des siècles de nouvelles connaissances à acquérir, des côtes à relever, des plantes, des arbres, des poissons, des oiseaux à décrire, des minéraux, des volcans à observer, des peuples à étudier, et peut-être à rendre plus heureux: car enfin une plante farineuse, un fruit de plus sont des bienfaits inestimables pour les habitants des Îles de la mer du Sud» ${ }^{17}$. Um lugar importante é, assim, atribuído às ciências naturais e à vontade de querer saber tudo para de tudo tomar posse e constituir uma súmula da natureza, que se pretende compreender de forma empírica e exacta, sob a forma de uma descrição, de um esboço ou da recolecção de plantas, aves, animais ${ }^{18}$.

$\mathrm{O}$ «espirito de conhecimento do globo» de que iam imbuídos os viajantes, que ambicionavam contribuir para o avanço da geografia, das ciências naturais e para um melhor conhecimento da humanidade, fez incorporar às equipagens dos navios «equipes» de cientistas cujas áreas de especialização se foram gradualmente complexificando. «Encouragée par l'État, l'exploration devient réellement scientifique, elle embarque une équipe de savants qualifiés, la récolte des observations est méthodiquement organisée et exploitée (...) Cook multiplie les détours, les aller et retour en tous sens. Les instruments de mesure s'accumulent, les équipes de scientifiques s'étoffent de voyage en voyage. Le voyage de Bougainville était celui de l'humaniste. Avec Cook, le temps est venue des spécialistes» ${ }^{19}$. Ou seja, as viagens de Cook são a manifestação de como a razão, a objectividade e o conhecimento rigoroso subiram a bordo dos navios e deram corpo ao protótipo do que era uma expedição científica, depurando o mítico e a metáfora a favor do empírico, da observação, da realidade. Desvanecia-se o mito da Terra Australis e descobria-se a Austrália ${ }^{20}$.

\footnotetext{
17 La Pérouse, 2005: 27. o sublinhado é meu.

18 Briand, 2005: 230.

19 Constant, 2006: XXVII.

20 Pimentel, 2003: 76.
} 


\begin{tabular}{|c|c|c|c|c|}
\hline Datas & Comandante & Nome & Cargo & Formação \\
\hline \multirow[t]{3}{*}{$1766-1769$} & $\begin{array}{l}\text { Louis-Antoine } \\
\text { de Bougainville }\end{array}$ & $\begin{array}{l}\text { Philibert de } \\
\text { Commerson }\end{array}$ & naturalista & \\
\hline & & $\begin{array}{l}\text { Charles Routier } \\
\text { de Romainville }\end{array}$ & cartógrafo & \\
\hline & & Vénon & astrónomo & \\
\hline \multirow[t]{7}{*}{$1768-1771$} & James Cook & Joseph Banks & naturalista & $\begin{array}{l}\text { Universidade de } \\
\text { Oxford }\end{array}$ \\
\hline & & Charles Green & astrónomo & \\
\hline & & $\begin{array}{l}\text { Daniel Charles } \\
\text { Solander }\end{array}$ & botânico & Discípulo de Lineu \\
\hline & & Sidney Parkinson & desenhador & \\
\hline & & $\begin{array}{l}\text { Alexander } \\
\text { Buchanan }\end{array}$ & desenhador & \\
\hline & & $\begin{array}{l}\text { Herman Diedrich } \\
\text { Sporing }\end{array}$ & pintor & \\
\hline & & Robert Molyneux & cartógrafo & \\
\hline \multirow[t]{9}{*}{$1785-1788$} & $\begin{array}{l}\text { Jean-François } \\
\text { de La Pérouse }\end{array}$ & $\begin{array}{l}\text { Joseph Lepaute } \\
\text { Dagelet }\end{array}$ & astrónomo & $\begin{array}{l}\text { Acad. de Ciências de } \\
\text { Paris Prof. } \\
\text { Matemática na Esc. } \\
\text { Militar }\end{array}$ \\
\hline & & Louis Monges & astrónomo & $\begin{array}{l}\text { Prof. Matemática na } \\
\text { Esc. Militar } \\
\end{array}$ \\
\hline & & \begin{tabular}{|l} 
Jean Honoré \\
Robert de Paul \\
de Lamanon
\end{tabular} & geólogo & $\begin{array}{l}\text { Acad. de Ciências } \\
\text { de Turim: } \\
\text { correspondente Ac. } \\
\text { Cienc Paris }\end{array}$ \\
\hline & & $\begin{array}{l}\text { Abbé Jean-André } \\
\text { Mongèz }\end{array}$ & $\begin{array}{l}\text { mineralogista } \\
\text { físico }\end{array}$ & $\begin{array}{l}\text { Redac. Journal de } \\
\text { Physique }\end{array}$ \\
\hline & & Prevost (tio) & naturalista & \\
\hline & & $\begin{array}{l}\text { Jean-Louis } \\
\text { Prévost } \\
\text { (sobrinho) }\end{array}$ & naturalista & \\
\hline & & \begin{tabular}{|l} 
Jean Nicolas \\
Dufresne
\end{tabular} & naturalista & \\
\hline & & $\begin{array}{l}\text { Paul Mérault de } \\
\text { Monneron }\end{array}$ & $\begin{array}{l}\text { engenheiro- } \\
\text { chefe }\end{array}$ & $\begin{array}{l}\text { Capitão no Corps } \\
\text { du Génie }\end{array}$ \\
\hline & & \begin{tabular}{|l|} 
Sébastien \\
Bernizet
\end{tabular} & $\begin{array}{l}\text { engenheiro- } \\
\text { geógrafo }\end{array}$ & \\
\hline
\end{tabular}




\begin{tabular}{|l|l|l|l|l|}
\hline Datas & Comandante & \multicolumn{1}{|c|}{ Nome } & \multicolumn{1}{c|}{ Cargo } & \multicolumn{1}{c|}{ Formação } \\
\hline & & $\begin{array}{l}\text { Gaspard Duché } \\
\text { de Vancy }\end{array}$ & desenhador & \\
\hline & $\begin{array}{l}\text { Nicolas } \\
\text { Collignon }\end{array}$ & jardineiro & Jardin du Roi \\
\hline & Claude Rollin & $\begin{array}{l}\text { cirurgião- } \\
\text { chefe }\end{array}$ & \\
\hline & & Pierre Guery & relojoeiro & \\
\hline & Simon Lavaux & cirurgião & \\
\hline & $\begin{array}{l}\text { Joseph Hugues } \\
\text { Boissieu de La } \\
\text { Martinière }\end{array}$ & $\begin{array}{l}\text { botânico e } \\
\text { naturalista }\end{array}$ & Univ. de Montpellier \\
\hline
\end{tabular}

Finalmente, importa considerar que, tendo estas viagens o propósito de aumentar a glória e a prosperidade de soberanos e nações e gerar um conhecimento científico com inquestionáveis repercussões ao nível do progresso, da liberdade e da felicidade dos povos, trazem para o cenário das navegações marítimas as rivalidades nacionais e as lutas europeias por poder e dominação.

A concorrência científica entre Inglaterra e França fazia-se também em mares longínquos e se a Grã-Bretanha tinha assumido, numa fase inicial, a iniciativa nas viagens de circum-navegação, era importante não deixar os rivais sozinhos no processo de medição do globo e de reconhecimento de mares e continentes. É então este cenário que enquadra o afã com que os oceanos foram, neste período, cruzados: por navios ingleses, franceses, espanhóis. E que, nesta conjuntura, os navios do comodoro Byron se tivessem encontrado com as embarcações de Bougainville no estreito de Magalhães ${ }^{21}$; que este navegador francês, na sua viagem de regresso, se tivesse cruzado ao largo de Cabo Verde com o inglês Carteret e lhe tivesse ocultado a rota e os objectivos da sua viagem ${ }^{22}$; e que um mês após Samuel Wallis ter tocado a ilha do Tahiti, Bougainville aí tivesse chegado; ou que a First Fleet se tivesse deparado com a expedição de La Pérouse em Botany Bay.

Tal como é assim que se explica o clima de competição editorial que se gera no mercado dos livros das viagens de longo curso.

${ }^{21}$ Constant, 2006: VI. Henry, 1773, vol. IV: 135

${ }^{22}$ Constant, 2006: XXIII 


\section{Contactos e distâncias: diálogos (?) E identidades Norte-Sul E NorTE-NorTe}

As rotas marítimas permitiram, particularmente desde o século $\mathrm{XV}$, a instalação de europeus em territórios novos e a disseminação da sua fé, da sua visão do mundo e dos seus conhecimentos. Criaram também um sentimento de pertença e de tomada de consciência de uma identidade própria em relação a outras culturas. Do mesmo modo, contribuíram igualmente para o desenvolvimento de sentimentos de superioridade europeia tanto sobre civilizações bárbaras e pagãs, como em relação às sociedades ibéricas e coloniais, consideradas pelos países europeus do Norte como decadentes e atrasadas e a necessitar imperiosamente de alterações e reformas profundas ${ }^{23}$.

$\mathrm{O}$ mundo era um palco que se abria às rivalidades europeias e às ambições dos estados para conquistar territórios longínquos e obter riquezas através do comércio. Esta transferência para o mar de uma parte significativa da hegemonia europeia reforçava a impossibilidade de o poder ficar concentrado nas mãos de uma única potência continental. Mas se «Una «testa coronada» no podía ciertamente encargarse de todo el comercio del mundo, podía aun utilizar su poder político para imponer decisiones importantes a favor de sus súbditos, cuyo dinamismo y ganancias venían a su vez a fortalecer el poder del príncipe» ${ }^{24}$.

O espaço geopolítico em que o Brasil se inseria assenta no extraordinário alargamento da importância do Atlântico Sul na vida europeia. Para além de ser um espaço onde a concorrência económica, política e científica entre os países europeus se manifestava, era incontestavelmente uma área onde as diferenças culturais podiam ser exageradas pelos viajantes e marinheiros quando se deparavam com sociedades que não eram as suas e sobre as quais queriam estabelecer qualquer tipo de domínio ou obter qualquer tipo de lucro ${ }^{25}$.

Também nesta perspectiva, a fronteira marítima brasileira apresenta-se como uma fronteira cultural, como um espaço culturalmente dinâmico, onde os diferentes grupos em presença manifestavam preconceitos, sentimentos de superioridade e desdém (mas também de solidariedade), visíveis nas relações entre as diferentes nações que se cruzavam nas cidades portuárias, fossem estas grandes portos, como o Rio de Janeiro ou Baía, localidades litorâneas

\footnotetext{
${ }^{23}$ Martinez Ruiz, 2010: 223; Para um estudo de caso que fundamenta conveniente e pontualmente esta afirmação v. Domingues, 12 (São Paulo, Novembro de 2010): 35-51.

http://www.brasiliana.usp.br/almanack/index.php/almanack/article/view/714/pdf

24 Bély, 2010: 133.

${ }^{25}$ Reynolds, 79/204 (Londres, May 2006): 161.
} 
mais modestas, como Santa Catarina ou Angra dos Reis, ou referências para o reagrupamento de navios, como a Ilha Grande.

Esses sentimentos emanam da literatura relacionada com as viagens (diários de bordo, relações de viagem, recompilações, colectâneas, documentação oficial escrita por quem recebia os viajantes, neste caso os luso-brasileiros). Esta informação textual é reflexo de «um jogo de imbricadas interdependências, no qual textos, sociedades e sujeitos se constituem uns aos outros, se inventam e reinventam. Em que as práticas sociais e os entendimentos culturais das mesmas são inseparáveis, constituindo-se e moldando-se mutuamente» ${ }^{26}$. As ordens sociais a partir das quais estes textos emergem assentavam em relações de tipo imperialista, tanto formal (que pressupõem, por exemplo, as relações entre Portugal e a colónia brasileira ou entre portugueses e estrangeiros), quanto informal, baseadas, por exemplo, na supremacia económica que caracterizou as relações entre Inglaterra e Portugal durante o século XVIII, vertidas no modo como os britânicos eram recebidos nos portos brasileiros; ou expressa na superioridade científica, mostrada na frase de Joseph Banks que sintetizava a falta de curiosidade ou inépcia científica dos portugueses em relação à história natural e à colónia brasileira: ««Indeed no one that I know of even tolerable curiousity has been here since Marcgrave and Piso about the year 1640, so it is easy to guess the state in which the natural history of such a countrey must be» ${ }^{27}$.

«Travellers write about what they see, and their perceptions are shaped by the cultural context from which they come and by all that they have read and experienced in that culture» ${ }^{28}$. É inegável que a noção que cada grupo tinha da sua identidade cultural moldou a sua percepção dos outros e isto, por sua vez, levou à auto-compreensão de cada grupo. Ora nesse sentido, a literatura de viagens e a informação a ela associada, seja ela de natureza textual ou visual (cartográfica, iconográfica ou tridimensional), é também um «teatro», uma encenação dentro de outra encenação, que reflecte sobre o mundo, os sistemas do poder, a edificação de impérios, a dominação do mundo e a hegemonia, e que verte essas estruturas e referências mentais na informação produzida ${ }^{29}$.

Esta afirmação articula-se com duas questões já enunciadas neste texto: a primeira consiste na forma como os europeus recém-chegados viram a socie-

${ }^{26}$ Xavier, s.d.: 2.

27 Banks, 1768 (http://www2.sl.nsw.gov.au/banks/series_03/download.cfm)

(consultado a 25.01.2010)

${ }_{28}$ Bassnett, 2002, vol. I: xi.

29 Os trabalhos historiográficos em torno deste tema são inúmeros. Veja-se, a título de exemplo, e por ser edição recente o dossier temático "Viagens e viajantes" da CEM, Cultura, espaço \& memória. Revista do CITCEM, 1 (Porto 2010). 
dade colonial luso-brasileira e como expressaram sentimentos incontestáveis de superioridade em relação a ela; e, num segundo plano, revela o modo como a concorrência entre Inglaterra e França se espelhava não apenas no domínio da execução das viagens de circum-navegação, mas também no da literatura de viagens, ou seja, do registo intelectual e disseminação dessas iniciativas.

\subsection{O Brasil e os luso-brasileiros na literatura de viagens}

Escusado será afirmar que o Brasil não é o cerne dos relatos destas viagens. Neles, a colónia aparece como uma mera escala depois da travessia, atribulada ou pacífica, do Atlântico Sul. Nestas viagens, os portos de eleição são dois: o Rio de Janeiro, escolhido por Byron, Cook e Bougainville, e Santa Catarina, preferido de La Pérouse. O argumento para esta última escolha radicou no facto de esta ilha ser um local habitualmente preferido pelos navios franceses em navegação pelo Atlântico Sul, mas também porque aqui os víveres eram abundantes e com uma procura menor e, para além disso, evitava-se o apertado controle que implicavam as ancoragens nas grandes cidades, como o Rio de Janeiro. De facto, convirá lembrar que o período em que foram realizadas estas expedições coincidiu com um aumento do temor em relação a possíveis projectos de invasão do Brasil por parte das potências europeias, a um consequente recrudescimento da legislação destinada a regulamentar a presença de estrangeiros na colónia, um aumento da vigilância sobre os navios que aí aportavam e uma reorganização de tropas e guarnições; e, paradoxalmente, também a um crescimento do contrabando e do comércio ilícito ${ }^{30}$.

Apesar de o encadeado factológico relacionado com cada uma destas expedições ser já sistematizado por historiadores como, por exemplo, Maria Fernanda Bicalho ou Jean Marcel Carvalho França, há algumas questões que gostaria de destacar ${ }^{31}$.

É um facto que, contrariamente a La Pérouse, nem Byron, Cook ou Bougainville passaram incólumes à vigilância apertada das autoridades administrativas luso-brasileiras. Depois de entrados na baía da Guanabara, os navios destas três expedições foram submetidos a autos de exame que obedeciam a regras estritas de protocolo que implicaram a deslocação a bordo do desembargador, oficiais de marinha, escrivães, pilotos, mestres e oficiais da mestrança, médicos e cirurgiões e, obviamente, intérpretes como John Burrish ou o tenente Francisco de Azevedo.

\footnotetext{
30 Bicalho, 1986.

31 Idem. França, 1999; 2000.
} 
O roteiro do questionário implicava que o capitão da embarcação fosse interrogado sozinho e lhe perguntassem o nome do comandante e da nau, lotação e tipo de armas, carga, porto de origem e de destino, rota e escalas, razões da arribada (abastecimento, avaria, doença) e seguidamente, se verificasse a exactidão das respostas através da comparação com depoimentos recolhidos junto de outros oficiais. Expressava-se também a permissão para compra de géneros alimentares e prestação de serviços, procurando que os estrangeiros demorassem o menor tempo possível no local, salvo se houvesse razões subreptícias para prolongar a estada ${ }^{32}$. Talvez considerações deste tipo expliquem que um navio espanhol proveniente de Montevideu com um carregamento de couro e prata, o Diligente, comandado por D. Francisco de Medina, esperasse oito meses por reparação dos danos sofridos num temporal em alto-mar. A arribada coincidiu com um período em que os cariocas aguardavam notícias do Sul, numa altura em que os portugueses planeavam atacar os espanhóis sediados no Rio Grande e quando tinham apresado uma nau espanhola em Santa Catarina ${ }^{33}$.

Quanto à vigilância imposta pelo governador de Santa Catarina, esta parece, tal como previa La Pérouse, bastante mais leve: D. Francisco de Barros não duvidou da sinceridade do francês quando este lhe atestou que «o fim da sua viagem se dirigia em utilidade de todas as nações, por ser esse objecto fazerem e adiantarem com a maior precizam e clareza as observaçõens Astronómicas e Geográficas, em que se empenhavão», centradas no mar Pacífico, Ásia e África, e que, para poderem prosseguir viagem, necessitavam de água, lenha, frutas e mantimentos. Permitiu-lhes, portanto, «com toda a política e civilidade», adquirir as provisões necessárias para prosseguir a sua viagem ${ }^{34}$.

As actividades de abastecimento e reparo permitiam um contacto mais próximo com a população, viabilizado pelas eventuais autorizações de desembarque às tripulações e pelo consentimento dado aos principais oficiais para residirem em terra. De facto, assim aconteceu com Byron, que, com o seu estado-maior, residiu numa villa próximo da cidade; mas menos com Bougainville, que a principio pôde deslocar-se pelo Rio, cear à beira-mar e assistir a um espectáculo de ópera a convite do conde da Cunha, mas que, após a chegada das notícias dos confrontos com os hispano-americanos no sul

32 Autos de exame, 14 de Setembro de 1764, Arquivo Histórico Ultramarino, Lisboa, CU, Rio de Janeiro, cx. 76, doc. 6898.

33 Doc, de 12 de Dezembro de 1767, AHU, Lisboa, CU, Rio de Janeiro, cx. 80. doc. 7232. Bicalho, 2003: 119.

${ }^{34}$ Oficio de Luís de Vasconcelos e Sousa a Martinho de Melo e Castro, de 9 de Janeiro de 1786, AHU, Lisboa, CU, Rio de Janeiro, cx. 127, doc. 10155. 
do Brasil, viu negada permissão para residir na casa anteriormente cedida a Byron e a liberdade de circulação na cidade cerceada; e ainda muito menos com Cook e Banks, que foram formalmente proibidos de desembarcar sem escolta luso-brasileira.

Os contactos com as populações locais, ainda que fugazes, permitiram aos viajantes a descrição da população. Este assunto remete para a velha, mas sempre pertinente, questão das identidades, nacional e colonial. O que, no caso presente significa contribuir para o entendimento de como «os representantes dos «mundos civilizados» ao ultrapassarem fronteiras geopolíticas se deparavam com incompreensões não só políticas como também culturais perante sociedades coloniais geradas por «outros mundos civilizados» no Atlântico Sul, com noções de domínio, poder e também de império.

Importa clarificar desde já que estes testemunhos têm um interesse informativo bastante menor que o veiculado através dos relatos da primeira viagem de circum-navegação de Cook, já analisados em outro local ${ }^{35}$. Apesar do indiscutível fascínio que a colónia luso-brasileira pudesse exercer pela beleza da paisagem, exuberância da flora, estranheza da fauna, riqueza mineralógica ou peculiaridade da organização social e do sistema governativo, a atenção que nestes relatos lhe é dada é reduzida. A explicação para este fenómeno poderá radicar na diferença notória na formação e nos interesses dos viajantes, com especial incidência em relação a Banks.

Corroborando esta afirmação, para Bougainville o Rio de Janeiro, conquistado uma vez pelas armas francesas, era bem conhecido dos leitores e amplamente descrito pelos viajantes, pelo que lhe parecia que fazer uma descrição detalhada da cidade podia tornar-se fastidioso ${ }^{36}$. Contudo, fundado na opinião de Commerson, reconhecia, sem grandes minúcias, que a colónia era riquíssima em espécies vegetais novas e um paraíso para os botânicos. E dava indicações detalhadas acerca das principais fontes de riqueza do Brasil que, na sua opinião - e contrariamente à de Banks, que valorizava acima de tudo as espécies vegetais, anexando ao seu diário uma lista exaustiva das espécies que tinha encontrado no Rio-, eram o contrabando com os territórios hispano-americanos, a par do ouro e das pedras preciosas extraídos de Rio das Mortes, Sabará e Serro Frio, apresentando ainda informações circunstanciadas sobre a dinâmica da economia colonial centrada na mineração ${ }^{37}$.

\footnotetext{
35 Domingues (São Paulo, Novembro 2010a): 35-51.

${ }^{36}$ Esta afirmação remete para a ocupação do Rio de Janeiro por René Duguay-Trouin entre Setembro e Novembro de 1711.

${ }^{37}$ Bougainville, 2006: 47.
} 
Quanto a La Pérouse, baseia-se no relato de Frézier para reparar que a autoridade soberana do monarca era lassa nestas partes da América, uma vez que os seus habitantes, vagabundos originários de várias partes do Brasil, eram súbditos apenas no nome e não reconheciam qualquer tipo de autoridade, para além de que eram pouco apoiados pelo governo, que não lhes concedia benefícios fiscais ou incentivos económicos. Paralelamente, fornece dados demográficos, avaliando a população em mais de 20000 almas; económicos, referindo a fertilidade da terra e abundância de frutas, legumes, cereais, madeiras, a inexistência de manufacturas e a importância da caça à baleia, monopólio da coroa controlado por uma companhia; e militares, mencionando as fortificações e guarnição.

Depois de ultrapassado o terror causado pela amaragem dos barcos franceses, os catarinenses eram descritos por La Pérouse como hospitaleiros e de «moeurs douces; ils sont bons, polis, obligeants mais superstitieux et jaloux de leur femmes, qui ne paraissent jamais en public». E os cariocas, por Bougainville como gente que se tinha mostrado francamente incomodada com o mau procedimento do vice-rei em relação aos franceses ${ }^{38}$. Quanto a Banks, apesar de reconhecer que os súbditos do vice-rei eram um «povo problemático», uma «gente iletrada e malcriada», «a mais preguiçosa e ignorante raça de todo o mundo», que, habitando um território fertilíssimo, em tudo semelhante às Índias Orientais, continuavam a depender de Lisboa para provimento de produtos tropicais como café e chocolate, reconhecia-lhes também alguma amabilidade e civilidade, «mais do que ele [britânico] poderia esperar» ${ }^{39}$.

Não obstante, penso que fica claro que nestes relatos se estabelece uma visão do Brasil marcada por um forte eurocentrismo norte-europeu. Seguindo uma perspectiva que parecia imperar na Europa, os «barbares de Ryo Janeiro» eram incontestavelmente colocados em plano inferior aos navegantes, fossem eles franceses ou britânicos. Mas, contrariamente ao relato de Banks, parece que nem Byron, Bougainville ou La Pérouse partiam do pressuposto, tantas vezes afirmado sem mais explicações por autores contemporâneos, que os $l u$ so-brasileiros estavam para os viajantes deste período num estádio inferior ao dos anglo-saxões e franceses na organização hierárquica da espécie humana ${ }^{40}$.

Nestes relatos, os argumentos que fundamentam a inferioridade dos lusobrasileiros assentam particularmente em questões relacionadas com sistemas governativos e com a arbitrariedade e o comportamento absoluto de figuras gradas da administração colonial. Ou emergiam quando surgiam fricções e atritos, despoletadas por actos que podiam ser considerados como arbitrários,

\footnotetext{
${ }^{38}$ La Pérouse, 2005: 42. Bougainville, 2006: 46.

39 Banks, 1768.

${ }^{40}$ Menezes e Bandeira, 2007: 31
} 
inconstantes ou contrários às leis da hospitalidade e da confiança mútua. Senão veja-se: para Byron, os luso-brasileiros eram inferiores porque governados por um vice-rei «as absolute a sovereign upon the earth». Do mesmo modo, António Rolim de Moura Tavares, conde de Azambuja, aparecia aos olhos dos leitores britânicos que liam os relatos de Cook, Banks e Hawkesworth como um ignorante que acreditava ainda no sistema geocêntrico e um déspota absoluto que exorbitava, a vários níveis e em muitas circunstâncias, os seus poderes, «as absolute as any Monarch on earth $»^{41}$. Impedia, por exemplo, indivíduos ilustrados de cumprir a missão de que iam incumbidos, uma missão destinada a beneficiar a Inglaterra e a humanidade. E, por último, a conduta afável do vice-rei conde da Cunha em relação a Bougainville era objecto de espanto, simultaneamente para os espanhóis ancorados no porto e para os cariocas, que advertiam que semelhante atitude cedo se alteraria. De facto, pouco depois de os ter recebido com mostras de civilidade, ceias à beira-mar e espectáculos de ópera, o vice-rei proibia a entrega do brigue que Bougainville queria comprar, bem como a aquisição das madeiras necessárias para o reparo dos navios e o alojamento do comandante e seu estado-maior numa casa que tinha, em 1765, sido ocupada por Byron ${ }^{42}$. Narrando os mesmos factos, António Alvares da Cunha testemunhava, por sua vez, a petulância e insolência do chefe da expedição franca, que teria vindo «tomar satisfações» por não lhe ter permitido pousar na chácara fora da cidade. Face ao comportamento do francês, o governador mandou-o sair do palácio e perante a impassibilidade de Bougainville e dos oficiais que o acompanhavam, que tinham permanecido sentados, afirmava que «se se demoraçe o fazia ir pela janella, porque elle repugnou levantar se da sua cadeira» ${ }^{43}$.

A altivez, arrogância e arbitrariedade, a par da ignorância e falta de interesse científico, reiteradamente consideradas pelos autores dos relatos como características dos governadores portugueses, eram, pois, contrastantes com a civilidade e amabilidade da população. Uma excepção seria o brigadeiro de infantaria Francisco de Barros de Morais Lozada Teixeira Homem, governador de Santa Catarina, que falava perfeitamente francês e foi considerado como detentor de vastos conhecimentos, dignos da maior credibilidade por La Pérouse ${ }^{44}$.

${ }^{41}$ Cook, 1768-1771.

${ }^{42}$ Hawkesworth, 1773, vol. I: 44. Bougainville, 2006: 44-45.

43 Oficio do conde da Cunha a Francisco Xavier de Mendonça Furtado, de 7 de Julho de 1767, AHU, Lisboa, CU, Río de Janeiro, cx. 81, doc. 7271.

${ }^{44} \mathrm{http} / /$ exlibris-ex-libris.blogspot.com/2007/06/o-marechal-francisco-de-barros-de.html (acessado em 02.07.2011). 
É inegável que nem todos os textos que integram a literatura de viagens apresentam a mesma qualidade literária ou merecem o mesmo crédito por parte dos leitores. A informação recolhida pelos viajantes resultava, frequentemente, de uma estadia curta e carecia de mais tempo de observação ${ }^{45}$. Por sua vez, os textos coligidos podiam resultar de uma selecção, de uma filtragem dessa informação em função dos interesses do momento, os da época e os dos leitores.

Apesar destas questões terem sido competentemente exploradas pela historiografia recente, parece-me também que, até ao momento, esta terá esquecido uma questão, que, na minha opinião, não é de somenos, a saber: qual a utilização que os portugueses faziam da literatura de viagens publicada na Europa? Como as descrições produzidas pela outra Europa sobre o Brasil - aquela que se dizia mais culta, mais científica, mais evoluída, mais ilustra$d a$ - , se repercutiram no reino e na colónia e foram utilizadas para correcção de algumas «fraquezas» relatadas pelos viajantes? Uma resposta cabal será, sem dúvida alguma, difícil, mas poder-se-á tentar contribuir para a sua elucidação.

Para tal, creio que será interessante considerar que, por vezes, a administração regional era instada a dar o seu parecer sobre os relatos de viagens, particularmente no que às regiões que governavam dizia respeito. É assim que o vice-rei, o conde de Resende, produziu um parecer «a respeito das circunstancias apontadas no extracto da viagem de La Peireuse incluzo no oficio de V. ${ }^{\text {a }}$ Ex. ${ }^{\text {a de }} 12$ de Janeiro do presente ano sobre algumas observações concernentes à ilha de Santa Catharina, indicando justamente os meios de se por esta Ilha no melhor estado de segurança». O parecer enquanto comentário é secundário. É fundamentalmente um pretexto ou um mote para José Luís de Castro expor a sua opinião de como o sistema de defesa da ilha se devia organizar e fortalecer ao nível da estratégia e da táctica, argumentando que a multiplicidade de fortes e a dispersão das tropas, bem como a bondade da natureza manifestada na fácil acessibilidade do porto, podiam ser factores de fraqueza e ineficácia na defesa da ilha. Esclareça-se ainda, e de modo pouco ingénuo, que o inquiridor e destinatário da memória era D. Rodrigo de Sousa Coutinho, o «relógio permanentemente adiantado» dentre os três ministro que viriam a constituir o governo de D. João no Rio de Janeiro ${ }^{46}$.

45 Rodrigues, s.d.: 4.

${ }^{46}$ Parecer a respeito das circunstancias apontadas no extracto da viagem de La Peireuse incluzo no oficio de $V^{a}{ }^{a x}{ }^{a}$ de 12 de Janeiro do presente ano sobre algumas observações concernentes à ilha de Santa Catharina, indicando justamente os meios de se por esta Ilha no melhor estado de segurança, de 14 de Setembro de 1799, AHU, Lisboa, CU, Río de Janeiro, cx. 174, doc. 12843; para uma biográfica sintética mas erudita de D. Rodrigo de Sousa Coutinho v. Diniz Silva, 2010: 133-157. 
2.2. Como o relato da primeira viagem de circum-navegação de James Cook aparece publicado em francês com o nome de "Supplément au voyage de M. de Bougainville» (1772) ou da importância do estudo das edições para a compreensão da concorrência Inglaterra-França

Estudos desenvolvidos por autores conceituados como François Moureau ou John Hattendorf analisam, com algum grau de eficácia, a importância que os livros relacionados com o mar e as obras técnicas de literatura marítima tiveram na economia do livro durante o Antigo Regime ${ }^{47}$.

Comentando o caso francês, Moureau parte de uma distinção clara entre livros destinados a uso profissional (livros de pilotagem, manuais de cabotagem), e obras dirigidas a um público mais vasto (diários de viagens, colectâneas). Não deixa pertinentemente de notar que «la concurrance scientifique de la France et de l'Angleterre se faisait sur les mers lointaines multiplia, dans un climat d'éditoriale compétition, les publications des voyages de long cour.» E repara ainda que, até à Guerra dos Sete Anos, os livreiros parisienses publicaram um número irrelevante de obras relacionadas com a literatura de viagens $^{48}$. Os franceses liam poucos relatos franceses, mas sobretudo liam traduções de Anson, Byron, Wallis, Cook, Phipps e doutros menos importantes, confiadas a editores holandeses, de que destaca os de Amesterdão, e a editores de cidades provinciais como Rouen, Lyon, Dieppe, Nantes, Brest, Le Croisic, Honfleur, La Rochelle e Bordeaux. Contudo, após os inícios do reinado de Luís XVI, editores como Desaint, Nyon, Pissot, Didot e Panckoucke, sob os seus próprios nomes ou debaixo da denominação social de l'Hotel de Thou, apareceram na paisagem editorial e dominaram o mercado livreiro, constituindo nalguns casos equipas de tradutores com o objectivo de divulgar junto dos leitores franceses, com a maior rapidez possível, as grandes viagens britânicas ${ }^{49}$.

Quanto à Grã-Bretanha, John Hattendorf afirma que o comércio dos livros marítimos em setecentos esteve concentrado em Londres, com editores como Mount \& Page, David Steel, Imray e Laurie \& Norie a dominarem o

\footnotetext{
${ }^{47}$ Para os mapas importa referir o notável estudo de Pedley, 23/37 (Belo Horizonte, Janeiro/Junho 2007): 7.

${ }^{48}$ V. por exemplo Moureau, 2005, 22.

49 Hawkesworth, 1773, vol. I: vj e ss. No prefácio dos editores franceses argumentavase que a necessidade de dar a conhecer ao publico francês as viagens britânicas justificava o recrutamento de uma equipe de tradutores, constituída por pessoas hábeis habituadas a exercer este tipo de função, por ingleses, por oficiais da marinha francesa versados em termos náuticos. Apostava-se na rapidez da difusão, na precisão e fidelidade de conteúdos, bem como na precisão dos termos náuticos e menos na uniformidade de estilo.
} 
mercado. Apesar de se imprimirem sobretudo livros práticos, dirigidos mais a marinheiros e menos a sábios, bibliófilos ou coleccionadores, o mesmo autor reconhece a importância de outro tipo de obras, relatos verdadeiros ou ficção, que conciliavam as peripécias de viagens com a descrição de países longínquos e povos estranhos e que tinham como denominador comum o mar ${ }^{50}$.

A confluência na obra Le livre maritime au siècle des Lumières. Edition et diffusion des connaissances maritimes destes dois estudos, que permitem comparar a economia do livro e a «geografia de editores-livreiros» entre a França e a Inglaterra, não é obviamente casual. Com eles, os editores pretenderam sublinhar o crescente interesse notório em relação à literatura de viagens, um interesse que envolvia navegantes, autoridades, editores, eruditos, geógrafos, naturalistas e leitores dos tipos mais variados. Mas pretenderam também chamar à atenção para a concorrência que nestes países se estabeleceu não apenas ao nível da execução das viagens, mas também no plano editorial, com repercussões ao nível da disseminação do conhecimento e da propaganda. «Que estas lecturas del mundo pasaran además al dominio publico, algo sólo posible a partir de la proliferación de ediciones accesibles y de la inclusión de noticias y relaciones a través de la prensa periódica, es el hecho que nos permite hablar aquí de una autentica mundialización de la propia idea del mundo, un fenómeno reconocible en los escritos de los miembros de la republica de las letras, pero que desborda con mucho los círculos de savants y phiosophes» $^{51}$

Contudo, para além da indiscutível utilidade das perspectivas apontadas por Moureau e Hattendorf, o tema da competição editorial pode ser perspectivado noutras direcções que, no actual momento, mais não serão do que um mero apontar de caminhos por onde a investigação poderá avançar. Porque terão que ser sustentados por um levantamento e uma análise meticulosos das edições, escorados numa sólida investigação nos arquivos, bem como na quantidade apreciável de informação já disponível on-line.

De uma forma provavelmente ingénua, acreditei, durante algum tempo, que apenas os países ibéricos tinham uma política de restrição em relação à divulgação das suas conquistas coloniais e que, neste âmbito, eram particularmente zelosos em relação ao espaço ibero-americano. Esta afirmação foi devidamente fundamentada em alguns artigos e provas académicas e baseada nos argumentos seguintes:

\footnotetext{
${ }^{50}$ Hattendorf, 2005: 59-68.

51 Pimentel, 2003: 226.
} 
1. as medidas legislativas emanadas pelas coroas ibéricas no sentido de proibir a presença de estrangeiros em território brasileiro;

2. a cerrada vigilância das autoridades coloniais no sentido de fazer cumprir a legislação e controlar a presença de estrangeiros, bem como regular os contactos que estes pudessem estabelecer com os habitantes das colónias;

3. a inexistência de publicações e a censura de informação sobre a América do Sul, que levava a que muitos manuscritos ficassem inéditos, que impressos fossem destruídos ou retirados de circulação, e que a informação disponível em arquivos e bibliotecas fosse acessível sob apertado controle ${ }^{52}$.

Notei ainda, através da análise de casos pontuais, que era inegável a concorrência entre a França e a Inglaterra, que se defrontavam e competiam com o objectivo de obterem controlo político e vantagens económicas. Um dos focos de animosidade no embate entre estes impérios era, então, Portugal e a sua colónia sul-americana, com os franceses a desenvolverem, em alturas específicas, projectos para ocupar territórios no Brasil. Foi o que ocorreu em 1710 e em 1711, com os ataques corsários de Jean-François Duclerc e Dugauy-Trouin. Ou ainda em1757, quando uma armada sob o comando do conde de Ache ancorou em frente do Rio de Janeiro e desembarcou oficiais e tropas, lançando pânico por toda a cidade. Estes planos de anexação seriam retomados cerca de cinco anos mais tarde, na sequência da Guerra dos Sete Anos, com o almirante Beaussier a planear uma invasão francesa com um contingente constituído por 22 navios e 5500 soldados $^{53}$.

Por seu turno, alturas houve em que os ingleses, que exerciam sobre a colónia brasileira um imperialismo informal possibilitado pelo peso do contrabando e do comércio ilícito, defenderam o controlo, integral ou parcial, da colónia brasileira. Foi o que ocorreu, por exemplo, em finais do século, quando na negociação de áreas com a França propunham a cedência de contrapartidas nas Filipinas, em troca dos territórios que os franceses pretendiam no Brasil ${ }^{54}$. Ou até mesmo fazendo planos de anexação imperial em relação a parte significativa do sub-continente sul-americano, corporizados na tomada de Buenos Aires em 1806 e 1807 ou na Convenção Secreta de 1807, que previa a transferência da corte portuguesa para o Brasil, bem como um considerável

${ }^{52}$ V. por exemplo, Domingues, 14/ 2 (Maringá, 2010b): 249-271.

53 Menezes e Bandeira, 2007: 35. Bicalho, 2003: 60-69.

${ }^{54}$ British Library, 1915, vol. IX: 143, carta de Lord Grenville a Henry Dundas, de 11 de Dezembro de 1798. 
apoio financeiro, militar e económico por parte da coroa britânica para evitar que D. João, príncipe regente, capitulasse perante Napoleão ${ }^{55}$.

Neste delicado jogo de equilíbrios, e não obstante se reconhecerem no plano científico como membros de «pleno direito» da República das Letras e nutrirem uma admiração universal por certas figuras, como Joseph Banks, britânicos e franceses não deixavam de tentar controlar informação, particularmente se esta podia ter importância geográfica e científica com repercussão a nível político e estratégico.

Um exemplo concreto para ilustrar esta afirmação consiste em Cook e nas instruções da primeira viagem de circum-navegação. Nas Secret Instructions to Captain Cook parece estabelecer-se uma distinção clara ao nível dos resultados da viagem: os que eram científicos strictu sensus -ou seja, as observações relacionadas com o trânsito de Vénus pelo disco solar- deviam ser dirigidos directamente e sem demoras ao secretário da Royal Society assim que o capitão chegasse a Londres. No entanto, quando se consideravam informações científicas com eventual significado político e estratégico — «the accounts of your Proceedings, and Copys of the surveys and discoveries you shall have made»-, estas deveriam ser transmitidas unicamente ao secretário do Almirantado.

Para além disso, Cook devia tomar percauções para que a informação não fosse disseminada, sem limites, pelos membros da tripulação: «upon your Arrival in England you are immediately to repair to this Office in order to lay before us a full account of your Proceedings in the whole course of your voyage; taking care before you leave the vessel to demand from the officers and petty officers the log books and journals they may have kept, and to seal them up for our inspection and enjoying them, and the whole crew, not to divulge where they have been until they shall have Permission so to do» ${ }^{56}$. Creio que este parágrafo elucida sobre as regras impostas pelo Almirantado a Cook (e, neste momento, não sei se a outros viajantes) acerca da disseminação de informação sobre matérias estratégica e politicamente sensíveis como eram, nesta altura, o processo exploratório dos mares do Sul e a competição entre potências pelo domínio de um hipotético continente habitável, defendido pelos teóricos da «terra firme».

Marta Torres Santo Domingo aponta que uma das consequências desta política era a divulgação tardia das «descrições oficiais» e o aparecimento de uma quantidade significativa de «relatos clandestinos ou anónimos», escritos

\footnotetext{
55 Arruda, 2010: 85.

${ }^{56}$ Secret instructions to captain Cook, 30 June 1768, in http://www.foundingdocs.gov.au/ resources/transcripts/nsw1_doc_1768.pdf (cons. 11.03.2011)
} 
por simples capelães ou marinheiros que, algumas vezes, assinavam com o nome de figuras gradas da expedição ${ }^{57}$. No que à viagem de Cook diz respeito, as limitações institucionais acima referidas não foram impeditivas de uma divulgação rápida dos relatos da viagem: logo em 1771 apareceu uma edição inglesa feita por um viajante anónimo, dedicada pelos editores aos Lords do Almirantado, a Joseph Banks e a Charles Solander, logo seguida por uma segunda edição publicada em Dublin. No ano seguinte aparece a tradução francesa de Fréville, outra em língua alemã, e ainda uma segunda edição francesa com alteração de título. Quanto ao relato oficial, o de John Hawkesworth, que concatenaria numa mesma obra os diários das viagens de Byron, Wallis, Carteret e Cook, viria a surgir dois anos após a finalização da última viagem.

A rapidez com que as edições e as traduções das viagens foram feitas remete para uma questão, aparentemente contraditória com o que afirmo sobre o controle de informação, mas que me parece espelhar, acima de tudo, o sentido que as navegações e a sua divulgação através do impresso tinham neste período, enquanto factores de afirmação de soberania e elementos decisivos na competição anglo-francesa pelo domínio de mares e continentes. Os relatos eram uma forma eficaz de transformar uma experiência pessoal em conhecimento público, testemunhos do mundo, reflexos da experimentação e da observação directa de outras naturezas e sociedades, influenciados na sua organização, desenvolvimento e conteúdos pela formação dos autores, pelas leituras feitas, pela selecção de argumentos e notícias, destinados a responder ao gosto da época e à curiosidade dos leitores ${ }^{58}$.

Mas podiam também ser utilizados como prova irrefutável de primazia no descobrimento e, consequentemente, de argumento válido em pretensões de soberania. Assim, apesar de reconhecer que Bougainville tinha chegado em primeiro lugar ao Tahiti, Banks escrevia que: «How necessary then will be for us to publish an account of our voyage as son as possible after our arrival if we mean that our own country shall have the Honour of our Discoveries! Should the French have published an account of Mr de Bougainville's voyage before that of the second Dolphin how infallibly will they claim the Discovery of Cypre or Otahite as their own and treat the Dolphins having seen it as a fiction (...). The Endeavour really did see it, a twelve month however after

57 Santo Domingo, VIII/441 (Barcelona, 2003). Como exemplo pontual, esta autora menciona o caso da primeira edição da viagem de Cook, publicada em 1771, de circulação restritíssima, e que por largo período de tempo permaneceu anónima. A autoria foi atribuída por Beaglehole ao marinheiro James Magra.

${ }^{58}$ Pimentel, 2003: 218. 
Mr De Bougainville; which if England chooses to exert her Prior Claim to it, as she may hereafter do, if the French settle it may be productive of very disagreeable consequences ${ }^{59} 7$.

Apesar de não ter sido aprovada oficialmente, a primeira edição de $A$ journal of a voyage round the world é noticiada em França no Journal des Sçavants (vol. I, Juin 1771, p. 344-351). O artigo, para além de notificar o «chumbo» dado por Banks e evocar a precedência dos trabalhos de $\mathrm{Mr}$. De Lalande na designação do Pacifico como o local mais apropriado para observar o trânsito de Vénus, publicava uma carta de Banks, sublinhando a sua condição de membro correspondente da Academia de Ciências de Paris, resumindo sumariamente a viagem. Destacava-se ainda o acolhimento «odioso» do vice-rei conde de Azambuja e faziam-se menções pontuais a Bougainville, sublinhando-se a exactidão e oportunidade das suas observações e rota ${ }^{60}$.

Este aspecto da disseminação, controle institucional e circuitos de informação é um dos caminhos que importará aprofundar na investigação, aqui apontado através da sistematização de um caso pontual já bem conhecido. Um outro, óbvio para perceber a concorrência Inglaterra/França, é o da leitura e comparação das edições e as traduções. Nesta linha de raciocínio não deixa de ser assaz curioso, e até mesmo irónico, constatar que a primeira versão francesa da viagem de circum-navegação de Cook, traduzida por Fréville em 1772, aparece junto do público francês com o título Supplément au voyage de M. de Bougainville; ou Journal d'un voyage autour du monde, fait par MM. Banks \& Solander E ainda que à relativamente curta notícia desta tradução, anunciada no Journal des Sçavants (vol. I, Decembre 1772, p. 771-781), apesar de não deixar de considerar a viagem do Cook como uma das navegações mais extraordinárias e curiosas feitas nos últimos cem anos, tivesse a necessidade de agregar duas cartas: uma de Philibert de Commerson sobre as produções naturais das ilhas de França, Bourbon e Madagáscar; e uma outra do barão de G. sobre a passagem Noroeste.

Apesar de franceses e ingleses serem considerados por Fréville como «as duas nações mais esclarecidas da Europa», este autor avaliava o contributo que os ingleses trouxeram à cartografia como sendo irrelevante. Aconselhava os leitores que quisessem acompanhar a rota de Cook a consultarem com benefício qualquer mapa-mundo ou, em alternativa, a carta que iniciava a Voyage autour du monde, de Bougainville. De igual modo, Gilles e Didier Robert de

\footnotetext{
59 Banks, 7 April 1771, in http://www2.sl.nsw.gov.au/banks/series_03/03_872.cfm

${ }^{60}$ Journal des Sçavants, Juin 1771, vol. I: 344-351.
} 
Vaugondy eram a referência para a visualização da hipotética ligação do mar do Norte e o mar do Sul através do pólo ${ }^{61}$.

Veja-se, ainda, o caso de Byron. No relato da viagem do comodoro, escrito por Hawksworth, fica claro que, até à saída do Rio de Janeiro, toda a tripulação cria que o destino final da viagem eram as Índias Ocidentais ${ }^{62}$. Sugiro que uma razão provável para semelhante precaução consistiria no facto de os mares do Sul serem desconhecidos e a travessia implicar grandes perigos. Apenas quando saiu da baía da Guanabara, Byron terá chamado os marinheiros e oficiais à coberta e informado que «upon certain discoveries, which it was thought might be of Great importance to our country, in consideration of which, the Lords Commissioners of the Admiralty had been pleased to promise them double pay and several other advantages, if during the voyage they should behave to my satisfaction ${ }^{63}$. $\mathrm{Na}$ linha de interpretação apontada da disputa franco-britânica, penso que é interessante a necessidade que Bougainville teve de comentar que, para executar fielmente a sua missão, as tripulações francesas não necessitaram de nenhum tratamento especial «tel que celui que les Anglais ont cru devoir faire aux équipages de Mr. Byron...C'est que la nation française est capable de vaincre les plus grandes difficultés, et que rien n'est impossible à ses efforts, toutes les fois qu'elle voudra se croire elle-même l'égale au moins de telle nation que ce soit au monde» ${ }^{64}$.

Ou seja, umas vezes subtilmente, sub-repticiamente, outras vezes de modo ostensivo, os autores, tradutores e compiladores deixavam escapar juízos de valor, comentários, apreciações sobre o oponente, que podem lançar algumas sombras sobre a «uniformidade da Europa das Luzes» defendida por autores como Juan Pimentel.

No incontornável Testigos del mundo, este autor sublinha o testemunho imparcial e fidedigno de compiladores como Charles de Brosses, Prévost, Maupertius ou Alexander Dalrymple ${ }^{65}$. A confirmar a afirmação de Pimentel, constate-se que as descrições do Brasil divulgadas por estes compiladores nas suas colectâneas de literatura de viagens seguem de perto os conteúdos que os navegadores escreveram nos seus diários, quer numa forma exacta, reproduzindo os textos ipsis verbis, quer noutra resumida, onde os compiladores ressaltavam apenas os aspectos que consideravam mais dignos de nota pela

\footnotetext{
61 Fréville, 1772: XV.

62 De modo idêntico, também a tripulação de Carteret ignorava o destino final da sua viagem, uma vez que as instruções dadas ao capitão eram secretas (Wallis, 1963: 17).

63 Hawkesworth, 1773, vol. I: 46.

64 Bougainville, 2006: 19.

65 Pimentel, 2003: 96.
} 
novidade ou pelo conteúdo, mas abstendo-se de acrescentar outras informações ou fazer quaisquer comentários.

Contudo, nem todos souberam ou quiseram manter a imparcialidade e objectividade no registo de mundos e coisas. Porque fica claro que a rivalidade latente entre França e Inglaterra podia tomar corpo sob a forma de textos, que manifestam tanto junto da elite científica como dos leitores comuns, de modo altamente eficaz e ilustrativo, sentimentos de auto-identidade, vertidos em expressões que depreciavam o outro e que valorizavam o eu. Se os marinheiros de cada país eram inegavelmente os mais corajosos, capazes e abnegados de toda a Europa e se os respectivos soberanos eram os mais empenhados e interessados na difusão do conhecimento e desenvolvimento do comércio em benefício de toda a humanidade, por vezes surge a necessidade de expressar uma crítica clara aos opositores.

Nesta linha, o compilador mais agressivo foi David Henry que nos resumos das diferentes narrativas das viagens, embora conseguindo manter alguma objectividade em relação aos britânicos, exprimia opiniões que criticavam simultaneamente portugueses e franceses. Se a imagem que perpassa dos ingleses era a de que eram corajosos, e contudo imprudentes, espertos, experientes, empenhados e capazes; os franceses, ao invés, aparecem como cheios de artifícios, pouco sinceros, reclamam a exclusividade da boa-educação mas, nalguns casos, conseguiam ser pouco cavalheirescos, de conduta iliberal, e algo desorganizados ${ }^{66}$. Por exemplo, ao descrever a destruição sofrida pelo La Boudeuse à saída de França, comenta: «And here a reflection will naturally arise, on that fatality, by which those who have the appointment of naval equipments, almost always destine for services of the most eminent danger, vessels totally inadequate for the propose. Hence arise orders and counter-orders, till the proper season for performing the most hazardous parts of the voyage is lost in the necessary preparation for making it» ${ }^{67}$.

Quanto aos portugueses, e na sequência do mesmo relato, eram considerados como bondosos e de comportamento civil, tentando compensar através de uma conduta que se pautava pela amabilidade e pela civilidade as arbitrariedades dos seus governantes. O vice-rei, contudo, era descrito como um tirano, altivo, exaltado e arrogante, o que ficava claramente patente na resposta dada a Bougainville sobre a saudação que o conde da Cunha considerava ser-lhe devida por todos os navios recém-chegados ao porto do Rio de Janeiro;

\footnotetext{
${ }^{66}$ Henry, 1773, vol. IV: 162. Não obstante, Bougainville era considerado no seu confronto com o vice-rei do Brasil como detentor dum espírito de orgulho próprio dum oficial e cavalheiro.

${ }^{67}$ Henry, 1773, vol. IV: 124.
} 
ou ainda na arbitrariedade e volubilidade das resoluções do vice-rei sobre a compra do um bote que acabou por ser proibida pelo vicerei ou em relação à negação de residência do estado-maior do capitão francês na chácara anteriormente ocupada por Byron.

Se é verdade que as amputações, inclusões ou digressões que estruturam as compilações da época, o que se valoriza ou escamoteia, nos falam, ao fim e ao cabo, do conhecimento que se tinha dos potenciais leitores - e se este conhecimento se tornou, nesta altura, num verdadeiro bem de consumo «comparável a um par de sapatos ou de meias»-, então comentários como os de Henry têm uma importância particularmente elucidativa na percepção do que os seus leitores queriam ler sobre britânicos, franceses e outros ${ }^{68}$. E que, na minha opinião, contribuem para a exacerbação de factores de natureza nacional que reflectem a concorrência entre indivíduos, povos e nações, com especial ênfase para «as duas nações mais esclarecidas da Europa». Creio que não deixa de ser interessante ressaltar que, uma vez mais, quando a concorrência entre franceses e britânicos se manifestava, como acontece em Henry David, a justificação para as grandes diferenças entre os súbditos das duas monarquias era uma vez mais acentuada pelas diferenças políticas «This reasoning [de Bougainville sobre as navegações na região das Falklands] may sound admirably well in the ears of the slaves of two arbitrary monarchs [França e Espanha], but will be equally ridiculed and condemned by every sensible subject of our happier, because limited, monarchy».

É indiscutível que a relação entre Ilustração e viagens é intensa. Na sua obra Testigos del mundo. Ciencia, literatura y viages en la Ilustración, Juan Pimentel sugere que a Europa Ilustrada é caracterizada por uma cultura comum e pelo surgimento de sentimentos de pertença e identidade que surgem com a intensificação do contacto com culturas extra-europeias. Esta tomada de consciência, que implica contacto e distância, é indissociável da expansão ocidental ocorrida durante a Idade Moderna ${ }^{69}$. Às afirmações deste historiador de que os impérios não são episódios de histórias nacionais e que a literatura de viagens jogou um papel decisivo para fazer dos habitantes de Paris ou Londres cidadãos do mundo, acrescentaria, sem discordar de forma absoluta com o que Pimentel propõe, mas no sentido de incorporar ao debate outras perspectivas, que a informação que emana da literatura de viagens aponta igualmente para a valorização da nação, de identidade nacional, do orgulho dos súbditos em relação à sua nação e ao seu soberano. Estes são factores a

\footnotetext{
68 Pimentel, 2003: 247.

69 Ibidem: 14.
} 
considerar na História da Europa e dos Impérios europeus durante a segunda metade de setecentos.

Uma outra conclusão não é mais do que um apontar de uma mera hipótese de trabalho: pretendo ter uma noção clara do caminho percorrido nos meios intelectuais europeus para que de Lafitau, e da sua admiração incondicional por Portugal, se chegasse a De Paw e Buffon, e à defesa da inferioridade do jovem continente americano e degenerescência da humanidade ameríndia e colonial ibérica nos trópicos americanos - e perceber se e como a literatura de viagens teria contribuído para isso. Sem que esqueça, obviamente, o meu principal objectivo: o Brasil colonial.

\section{BIBLIOGRAFÍA}

Arruda, José Jobson de Andrade, "A abertura dos portos e a ruptura do sistema colonial luso-brasileiro", Jorge Couto (org.) Rio de Janeiro, capital do Império Português (1808-1821), Lisboa, Fundação Calouste Gulbenkian e Tribuna da História, 2010: 75-116.

Bassnett, Susan, "Introduction", Jennifer Speaker (org.), Literature of travel and exploration: an Encyclopaedia, vol. I, New York, Fitzroy Dearborn Publishers, 2002: xi-xv. http://cw.routledge.com/ref/travellit/introduction.pdf (cons. 06.06.2013).

Bély, Lucien, "Comercio y diplomacia: la imagen de la America española en los asuntos internacionales a principios des siglo XVIII", David González Cruz (ed.), Extranjeros y enemigos en Iberoamérica: la visión del otro del Imperio Español a la Guerra de la Independencia, Madrid, Silex Ed., 2010: 123-136.

Bicalho, Maria Fernanda, A cidade e o Império: o Rio de Janeiro no século XVIII, Rio de Janeiro, Civilização Brasileira, 2003.

Briand, Catherine. "L'illustration du livre de voyage maritime au XVIIIe siècle", Annie Charon, Thierry Claerr et François Moureau, (comp.), Le livre maritime au siècle des Lumières. Edition et diffusion des connaissances maritimes (1750-1850), Paris, Presses de l'Université de Paris-Sorbonne, 2005: 219-243.

Charon, Annie, Claerr, Thierry et Moureau, François (comp.), Le livre maritime au siècle des Lumières. Edition et diffusion des connaissances maritimes (1750-1850), Paris, Presses de l'Université de Paris-Sorbonne, 2005. http://books.

google.pt/books?id=MKT JzFPzEcC\&pg=PA9\&lpg=PA9\&dq=annie+charon,,+ thierr $\mathrm{y}+$ claerr + et + fran $\% \mathrm{C} 3 \% \mathrm{~A} 7$ ois\&source $=$ bl\&ots=nCifGoakVl\&sig=URcQvinQz48 LPtfSZeeOm4gXwdg\&hl=pt-PT\&sa=X\&ei=MKqwUYrZHZKM7Aaqt4HYBw\& ved=0CEYQ6AEwBDgK (cons.06.06.2013). 
Constant, Louis, "Introduction", in Louis Antoine de Bougainville, Voyage autour du monde par la frégate la Boudeuse et la flûte l'Étoile, Paris, La Découverte Poche, 2006: i-xxix.

Diniz-Silva, Andrée Mansuy, "Uma figura central da corte portuguesa no Brasil: D. Rodrigo de Sousa Coutinho", In Ismênia Martins, e Márcia Motta (orgs.), 1808. A corte no Brasil, Niterói, Editora da UFF, 2010: 133-157.

Domingues, Ângela, “'Desde Piso e Marcgrave que ninguém com curiosidade tolerável descreveu a natureza brasileira': os relatos de Cook, Banks e Parkinson e a construção de imagens do Brasil colonial", Almanack Braziliense, 12 (São Paulo, Novembro de 2010a): 35-51. http://www.almanack.unifesp.br/index.php/almanack/ article/view/714 (cons. 06.06.2013).

Domingues, Ângela, “For the relief of Man's state or the advancement of national interests? A percepção da natureza brasileira ao serviço das nações e da humanidade nos escritos dos viajantes do século XVIII", Diálogos-DHI/PPH/UEM, 14/2 (Maringá, 2010b): 249-271. http://www.google.pt/\#gs rn=16\&gs ri=psy-ab\&suggest $=\mathrm{p} \& \mathrm{pq}=$ for $\% 20$ the $\% 20$ relief $\% 20$ of $\% 20$ man's $\% 20$ estate $\& \mathrm{cp}=49 \& \mathrm{gs}$ $\underline{\mathrm{id}=5 \mathrm{a} \& \mathrm{xhr}=\mathrm{t} \& \mathrm{q}=\text { for }+ \text { the }+ \text { relief }+ \text { of }+ \text { man's }+ \text { state }+ \text { or }+ \text { the }+ \text { advancement } \& \text { es }}$ $\underline{\text { nrs }}=$ true $\& \mathrm{pf}=\mathrm{p} \&$ sclient $=$ psy-ab\&oq $=$ for + the + relief + of + man's + state + or + the + adva ncement $+\& g s \_\& p b x=1 \& b a v=$ on. 2 ,or.r $=$ qf. $\& f p=f 7 a 0 d 0 c b 4 e 822143 \& b i w=1280$ $\underline{\text { \&bih }=685}$ (cons. em 06.06.2013).

França, Jean Marcel Carvalho, Visões do Rio de Janeiro colonial. Antologia de textos, 1531-1800, Rio de Janeiro, José Olympio Ed. e Ed. UERJ, 1999.

França, Jean Marcel Carvalho, Outras visões do Rio de Janeiro colonial. Antologia de textos, 1582-1808, Rio de Janeiro, José Olympio Ed., 2000.

Gerbi, Antonello, O Novo Mundo. História de uma polémica (1750-1900), São Paulo, Companhia das Letras, 1996.

Hattendorf, John, "Le livre maritime dans le monde anglophone, 1750-1850", Annie Charon, Thierry Claerr et François Moureau (comp.), Le livre maritime au siècle des Lumières. Edition et diffusion des connaissances maritimes (1750-1850), Paris, Presses de 1'Université de Paris- Sorbonne, 2005: 59-68.

Junqueira, Mary Anne, "Charles Wilkes, a US Exploring Expediton e a busca dos Estados Unidos da América por um lugar no mundo (1832-1842)", Tempo 25 (Niterói, Julho 2008): 120-138.

Macedo, Jorge Borges de, História da Diplomacia Portuguesa. Constantes e linhas de força. Estudo de Geopolítica, Lisboa, Tribuna da Historia em colaboração com o Instituto de Defesa Nacional, 2. ${ }^{\mathrm{a}}$ edição, 2006.

Martínez Ruiz, Enrique, "Viajeros extranjeros en la España del cambio de siglo: de Carlos IV a la Guerra de la Independencia”, David González Cruz (ed.), Extran- 
jeros y enemigos en Iberoamérica: la visión del otro del Imperio Español a la Guerra de la Independencia, Madrid, Silex Ed., 2010: 219-234.

Menezes, Pedro da Cunha e Bandeira, Júlio, O Rio de Janeiro na rota dos mares do Sul: iconografia do Rio de Janeiro na Austrália, Rio de Janeiro, Andrea Jakobsson Estúdio, 2. ${ }^{\text {a }}$ edição, 2007.

Moureau, François, "Le livre maritime dans l'économie de la librairie française. Des origines au milieu du XVIIIe siècle", Charon, Annie, Claerr, Thierry et Moureau, François (comp.), Le livre maritime au siècle des Lumières. Edition et diffusion des connaissances maritimes (1750-1850). Paris, Presses de l'Université de ParisSorbonne, 2005: 9-24.

Newell, Jennifer, "Irresistible objects: collecting in the Pacific and Australia in the reign of George III", Kim Sloan (ed.), Enlightenment. Discovering the world in the eighteenth century, Londres, The British Museum Press, 2003: 246-256.

Novais, Fernando, Portugal e Brasil na crise do Antigo Sistema Colonial (1777-1808), São Paulo, HUCITEC, 4. ${ }^{a}$ edição, 1986.

Pedley, Mary Sponberg, “O comércio de mapas na França e na Grã-Bretanha durante o século XVIII”, Vária História, 23/37 (Belo Horizonte, Janeiro/Junho 2007): 15-29.

Pimentel, Juan, Testigos del mundo. Ciencia, literatura y viajes en la Ilustración, Madrid, Marcial Pons, Historia Estudios, 2003.

Reynolds, Susan, "Empires: a problem of comparative history", Historical Research, 79/204 (Londres, May 2006): 151-165.

Robson, John, "A comparison of the charts produced during the Pacific voyages of Louis Antoine de Bougainville and James Cook", Glyndwr Williams (ed.), Captain Cook: explorations and reassessments, Woodbridge, The Boydell Press, 2004: 137-152. http://books.google.pt/books?id=VqDHGruzcIC\&pg=PA137\&lpg= PA137\&dq $=\mathrm{ohn}+$ robson $+\mathrm{a}+$ comparison $+\mathrm{of}+$ the + charts + produced \&source $=\mathrm{bl} \&$ ots =derTuDAIGd\&sig=ze2p7rJPb98MByi7Q4-J92AtwYQ\&hl=pt-PT\&sa=X\&ei=Gq ywUeyEDePC7AaExIHADw\&ved $=0$ CEoQ6AEwBA\#v $=$ onepage \&q $=$ john $\% 20$ robson $\% 20 \mathrm{a} \% 20$ comparison $\% 20 \mathrm{of} \% 20$ the $\% 20$ charts $\% 20$ produced $\& \mathrm{f}=$ false (cons. 06.06.2013).

Rodrigues, José Damião, "Centros e periferias no olhar dos viajantes estrangeiros. Para uma leitura crítica da literatura de viagens" (dactilografado).

Santo Domingo, Marta Torres, "Los viajes del capitán Cook en el siglo XVIII. Una revisión bibliográfica”, Biblio $3 W$. Revista bibliográfica de Geografía y Ciencias Sociales, VIII/ 441 (Barcelona, 20 de Abril de 2003) http://www.ub.es./geocrit/ b3w-441.htm (cons. abril 2013).

Subrahmanyam, Sanjay, "A tale of three empires. Mughals, Ottomans and Habsburgs in a comparative context”, Common Knowledge, 12/1 (Durham, Winter 2006): 
66-92. http://muse.jhu.edu/login?uri=/journals/common_knowledge/v012/12.1 subrahmanyam.html. (cons. 30.04.2011).

Turchin, Peter, Adams, Jonathan M. y Hall, Thomas D., "East-West orientation of historical empires and modern states", Journal of World-System Research, XII/II (North Carolina e Utah, December 2006): 219-229.

Turchin, Peter, "A theory for formation of large empires", Journal of Global History, 4 (Londres, 2009): 191-217.

Wallis, Hellen (ed.), Carteret's voyage round the world, 1766-1769, 2. ${ }^{a}$ série, vol. CXXIV e CXXV, Londres, The Hakluyt Society by Cambridge University Press, 1963.

Xavier, Ângela Barreto, "Nobres per geração. A consciência de si dos descendentes de portugueses na Goa setecentista" (texto dactilografado).

\section{FonTES IMPRESAS}

Banks, Joseph, The Endeavour Journal of Joseph Banks, vol. I, November 1768, Rio de Janeiro http://www2.sl.nsw.gov.au/banks/series 03/download.cfm) (cons. 25.01.2010)

Bougainville, Louis Antoine de, Voyage autour du monde par la frégate la Boudeuse et la flûte l'Étoile, Paris, La Découverte Poche, 2006.

British Library, Historical Manuscripts Commission. Reports on the manuscripts of the JB Fortescue esp. Preserved at Dropmore, Londres, Printed for His Majesty's Stationery Office, vol. IX, 1915.

Cook, James. James Cook's Journal of remarkable occurrences aboard His Majesty's Bark Endeavour, 1768-1771. http://southseas.nla.gov.au/journals/cook remarks/001.html)

Fréville, M. de, Supplément au voyage de M. de Bougainville ou Journal d'un voyage autour du monde, Fait par MM. Banks \& Solander, anglois, en 1768,1769, 1770, 1771. Traduit de l'Anglois par $M$ de ..., Paris, Chez Saillant \& Nyon Libraires, 1772.

Hawkesworth, John, An account of the voyages undertaken by the order of His Present Majesty for making discoveries in the Southern Hemisphere and successively preformed by Commodore Byron, Captain Wallis, Captain Carteret and Captain Cook in the Dolphin, the Swallow and the Endeavour, drawn up from the journals which were kept by the several commanders, and from the papers of Sir Joseph Banks, Bart., London, vol. I, 1773 (http://southseas.nla.gov.au/journals/hv23/title. html) (cons. 08.03.2010). 
Hawkesworth, John, Relation des voyages entrepris par l'ordre de Sa Majesté Britannique et successivement exécutés par le Commodore Byron, le Capitaine Carteret, le Capitaine Wallis et le Capitaine Cook, dans les vaisseaux le Dauphin, le Swallow, et l'Endeavour. Traduite de l'Anglois, À Paris, Chez Saillant et Nyon et Panckoucke, 1774, tomos I a VIII.

Henry, David, An historical account of all the voyages round the world: performed by English navigators: including those lately by order of His preset Majesty: the whole faithfully extracted from the journals of the voyagers; Drake, undertaken in 1577-80, Cavendish, 1586-88; Cowley, 1683-86; Dampier, 1689-96: Cooke, 170811; Rogers, 1708-11; Clipperton and Shelvocke, 1719-22, Anson, undertaken in 1740-44; Byron, 1764-66; Wallis, 1766-68, Carteret, 1766-69; and Cook, 1768-71; together with that of Sydney Parkinson... and the voyage of Mons. Bougainville... to which is added an appendix; containing the journal of a voyage to the North Pole, by the Hon. Commodore Phipps, and captain Lutwidge (1773), London, F. Newberry, vol. IV, 1773.

Journal des Sçavants, vol. I, Juin 1771.

Journal des Sçavants, vol. I, Decembre 1772.

Lafitau, Joseph-François, Histoire des découvertes et conquestes des Portugais dans le nouveau monde. Avec des figures en taille-douce par Le R.P..., A Paris, Chez Saugrain Père e Jean-Baptiste Coignard Fils, tome I, 1734.

La Pérouse, Jean- François de, Voyage autour du monde sur l'Astrolabe et la Boussole (1785-1788), choix de textes, introduction et notes de Hélène Patris, Paris, La Découverte, 2005.

Secret instructions to captain Cook, 30 June 1768 in http://www.foundingdocs.gov. au/resources/transcripts/nsw1 doc 1768.pdf (cons. 11.03.2011).

Fecha de recepción: 6/07/2011

Fecha de aceptación: 23/09/2011 


\section{Oficiales, caballeros y competidores: «Brasil», estudio de las expediciones de circunnavegación en la Era de la Ilustración}

En este artículo se pretende analizar las imágenes de Brasil a través de la literatura de viajes obtenida gracias a los viajes de circunnavegación llevados a cabo en la segunda mitad del siglo XVIII. La manera en la que Brasil fue representada en los relatos de Cook, Byron o Bougainville y las colecciones de relatos de viaje que se difundieron gracias a estos viajes no ha sido debidamente considerada y valorada. Esta evaluación es necesaria para apreciar la importancia de la colonia Brasileña a escala global y particularmente en el Atlántico Sur, así como los juegos de poder que alli tuvieron lugar. Asimismo, en la carrera por «dominar el mundo» en la Europa del siglo XVIII, la mayor competencia se vio entre Francia e Inglaterra. En este proceso, la atención que ambos países dedicaron a Brasil a través de proyectos de anexión, además de la dominación informal, se vio reflejada en la importancia que tenían el comercio ilegal y el contrabando británico o los intereses científicos y la curiosidad. Por lo tanto, el comprender la competencia entre estos países también a nivel de literatura de viajes, producción y diseminación de información - es decir, propaganda-puede contribuir a un mejor conocimiento de lo que Brasil y Portugal realmente significaban para la Europa del siglo XVIII.

Palabras Clave: Brasil colonial; viajes de circunnavegación; literatura de viajes; imperios europeos; identidades.

\section{Officers, gentlemen and competitors: «Brazil» on circumnavigation voyages of the Age of Enlightenment}

It is intended to analyze the images of Brazil through travel literature produced with the circumnavigation voyages of the second half of the eighteenth century. The manner in which Brazil was represented in the accounts of Cook, Byron or Bougainville and collections of travel writing that spread these journeys has not been duly considered and appreciated. This evaluation is essential to realize the importance of the Brazilian colony on a global scale and especially in South Atlantic, as well as the games of power that then unfolded. Similarly, in the attempt to "dominate the world» occurred in eighteenth-century Europe, the competition was mainly between France and England. In this process, the attention that both countries put in Brazil expressed in annexation projects, as well as in informal domination, reflected in the weight that illegal trade and British smuggling or scientific interest and curiosity had. Therefore, to understand the competition between these countries also at the level of travel literature, production and dissemination of information - and therefore propaganda-can contribute to a better understanding of what Brazil and Portugal meant to eighteenth century Europe.

KeY words: Colonial Brazil; Circumnavigation voyages; Travel literature; European empires; Identities. 